\title{
Carps, Catla catla, Cirrhinus mrigala and Hypophthalmichthys molitrix Are Resistant to Experimental Infection with Tilapia Lake Virus (TiLV)
}

\author{
Pravata Kumar Pradhan ${ }^{1, *}$, Dev Kumar Verma ${ }^{1}$, Shrish Chandra Yadav ${ }^{1}$ (D), Atul Krishna Dev ${ }^{1}$, \\ Thangaraj Raja Swaminathan ${ }^{2} \mathbb{D}$, Anutosh Paria ${ }^{1}$, Rajendran Kooloth Valappil ${ }^{3}$ and Neeraj Sood ${ }^{1, *}$
}

1 ICAR-National Bureau of Fish Genetic Resources, Canal Ring Road, P.O. Dilkusha, Lucknow 226002, Uttar Pradesh, India; devnbfgr@rediffmail.com (D.K.V.); 143shrish@gmail.com (S.C.Y.); atulkrsnadev@gmail.com (A.K.D.); anutosh.paria@icar.gov.in (A.P.)

2 Peninsular and Marine Fish Genetic Resources Centre, ICAR-NBFGR, CMFRI Campus, Kochi 682018, Kerala, India; T.Swaminathan@icar.gov.in

3 ICAR-Central Institute of Fisheries Education, Versova, Andheri (W), Mumbai 400061, Maharashtra, India; kvrajendran@cife.edu.in

* Correspondence: Pravata.Pradhan@icar.gov.in (P.K.P.); Neeraj.Sood@icar.gov.in (N.S.)

\section{check for} updates

Citation: Pradhan, P.K.; Verma, D.K. Yadav, S.C.; Dev, A.K.; Swaminathan, T.R.; Paria, A.; Valappil, R.K.; Sood, N. Carps, Catla catla, Cirrhinus mrigala and Hypophthalmichthys molitrix Are Resistant to Experimental Infection with Tilapia Lake Virus (TiLV). Fishes 2021, 6, 56. https://doi.org/10.3390/ fishes 6040056

Academic Editor: Maria Angeles Esteban

Received: 29 August 2021

Accepted: 27 October 2021

Published: 1 November 2021

Publisher's Note: MDPI stays neutral with regard to jurisdictional claims in published maps and institutional affiliations.

Copyright: (c) 2021 by the authors. Licensee MDPI, Basel, Switzerland. This article is an open access article distributed under the terms and conditions of the Creative Commons Attribution (CC BY) license (https:/ / creativecommons.org/licenses/by/ $4.0 /)$.
Abstract: Tilapia tilapinevirus, also known as tilapia lake virus (TiLV), is an emerging fish virus that primarily affects tilapines. However, the virus has also been detected in a few non-tilapines. As tilapia is generally farmed in polyculture systems along with carps in South Asian countries, there is a likelihood that TiLV-infected tilapia can transmit the virus to the co-cultured species. In view of the above, the susceptibility of three carp species, namely catla (Catla catla), mrigal (Cirrhinus mrigala) and silver carp (Hypophthalmichthys molitrix) was evaluated vis-à-vis tilapia, following experimental infection with TiLV. No clinical signs and histopathological alterations could be observed in carps. RT-qPCR revealed that TiLV copy numbers in liver and brain of all the three carps were almost negligible and did not show any increase with time, suggesting that the virus did not replicate in liver and brain, the target organs of TiLV. Further, TiLV could not be isolated from pooled liver and brain tissues of carps using permissive CFF cell line. On the contrary, in tilapia, typical clinical signs and histopathological lesions were observed and there was significant increase in TiLV copy number up to 6 days post-injection. Furthermore, the virus was successfully isolated from pooled liver and brain tissue of infected tilapia. From the above findings, it could be concluded that C. catla, C. mrigala and H. molitrix are resistant to TiLV infection and unlikely to be carriers for this virus.

Keywords: tilapia lake virus; tilapia; carps; susceptibility; polyculture; RT-qPCR

\section{Introduction}

Tilapia tilapinevirus, also known as Tilapia lake virus (TiLV), is a negative-sense singlestranded, ten-segmented RNA virus belonging to the genus Tilapinevirus under the family Amnoonviridae [1]. Following the first report of TiLV disease from Israel in 2014, there are reports of the disease from 16 countries across four continents, i.e., North America, South America, Asia, and Africa [2,3]. Tilapines, the second-most-farmed freshwater fish globally, are primarily affected by the disease with mortality ranging from 5\% to $100 \%$ [4]. The affected farmed tilapines include Nile tilapia (Oreochromis niloticus), red tilapia (Oreochromis sp.) and hybrid tilapia (O. niloticus x O. aureus, O. niloticus x O. mossambicus) [3]. A number of wild tilapines including Sarotherodon galilaeus, Tilapia zilli, O. aureus and Tristamella simonis intermedia have also been reported to be affected by the disease [2]. In addition to the tilapines, the giant gourami (Osphronemus goramy) has been reported to be naturally affected by the disease [5]. The TiLV nucleic acid has also been detected in wild river barb (Barbonymus schwanenfeldi) and barramundi (Lates calcarifer) [6,7]. On the other hand, a number of freshwater fishes have been found to be resistant to TiLV infection following 
experimental challenge; these include rohu (Labeo rohita), common carp (Cyprinus carpio), silver barb (Barbodes gonionotus), iridescent shark (Pangasianodon hypophthalmus), striped snakehead (Channa striata), walking catfish (Clarias macrocephalus), climbing perch (Anabas testudineus), snakeskin gourami (Trichogaster pectoralis), Asian seabass (Lates calcarifer), pearlspot (Etroplus suratensis), canara pearlspot (E. canarensis) and orange chromide (Pseudetroplus maculatus) $[4,8,9]$. Importantly, there has been no report of TiLV disease in several species co-cultured with tilapia $[2,10,11]$.

In South Asia, tilapia is mainly cultured along with Indian major carps and Chinese carps in polyculture system [12,13]. Several farms culturing different species may share the same water source, leading to transmission of the pathogens between the farms and species. Although there is no report of TiLV disease in carps co-cultured with tilapia in natural conditions [11,13], but there is a paucity of conclusive evidence regarding the susceptibility of carps and other commercially important fish species to TiLV. Moreover, there is a likelihood that some of these fish species may act as carrier and transmit the virus to other species [14]. Therefore, the aim of this study was to evaluate the susceptibility of some of the carps to experimental infection with TiLV.

\section{Materials and Methods}

\subsection{Fishes}

Healthy juveniles $(\mathrm{n}=30)$ of each fish species i.e., catla, Catla catla $(19.3 \pm 1.72 \mathrm{~g})$; mrigal, Cirrhinus mrigala $(18.1 \pm 2.1 \mathrm{~g})$; silver carp, Hypophthalmichthys molitrix $(22.3 \pm 1.69 \mathrm{~g})$ and Nile tilapia, Oreochromis niloticus $(17.9 \pm 2.9 \mathrm{~g})$ were procured from the Fish Germplasm Resource Centre of ICAR-National Bureau of Fish Genetic Resources, Lucknow. The fishes were maintained in separate fiber-reinforced plastic (FRP) tanks, each containing $600 \mathrm{~L}$ water and fed with a commercial diet (ABIS, IB Group, Rajnandgaon, Chhattisgarh, India) @ $2 \%$ body weight. About $30 \%$ of the water was exchanged daily and water quality parameters such as temperature, dissolved oxygen and $\mathrm{pH}$ values were recorded to be $28.7 \pm 1.5^{\circ} \mathrm{C}, 5.87 \pm 0.36 \mathrm{mg} \mathrm{L}^{-1}$ and $7.7 \pm 0.34$, respectively. Before the experiment, five fish of each species were randomly collected and screened for TiLV using RT-qPCR [15] and found to be free from the TiLV infection.

\subsection{Challenge Study and Sample Collection}

Twenty-five fish from each species were injected intraperitoneally with $100 \mu \mathrm{L}$ supernatant from CFF cells infected with TiLV $\left(1 \times 10^{-3.4} \mathrm{TCID} 50 \mathrm{~mL}^{-1}\right)$, as reported earlier [8]. For investigating the mortality pattern, ten fish from each species were kept in FRP tanks separately. For sampling, three fish from each group were euthanized using $200 \mathrm{mg} \mathrm{L}^{-1}$ MS-222 (Sigma-Aldrich, St. Louis, MO, USA) at 1, 6 and 12 days post-injection (dpi). Thereafter, tissues (liver and brain) were collected in RNAlater for RT-qPCR (Sigma-Aldrich, St. Louis, MO, USA), whereas for histopathology, the liver tissue was preserved in $10 \%$ neutral buffered formalin (NBF). For virus isolation, pooled tissues (liver and brain) from three infected fish of each species at 6 dpi were taken in L-15 medium containing 10\% FBS. The experiments involving live fishes were approved by the Institutional Animal Ethics Committee.

\subsection{Histopathology}

The NBF preserved tissues were dehydrated using ascending grades of alcohol, cleared in chloroform and subsequently embedded in paraffin wax. Sections (4 $\mu \mathrm{m}$ thickness) were cut using microtome (Leica, Wetzlar, Germany) and stained with hematoxylin and eosin (H\&E). Thereafter, the slides were examined using a compound microscope (Olympus, Tokyo, Japan).

\subsection{Extraction of RNA and cDNA Synthesis}

Total RNA was extracted from $30 \mathrm{mg}$ of each tissue (liver and brain) of TiLV-challenged fishes using $1 \mathrm{~mL}$ TRIzol ${ }^{\circledR}$ Reagent (Ambion, Carlsbad CA, USA), following manufacturer's 
protocol. RNA concentration and quality were estimated using Denovix DS-11 spectrophotometer (Denovix Inc., Wilmington, DE 19810, USA). Subsequently, one microgram of total RNA was used for cDNA synthesis using First-strand cDNA synthesis kit (Thermo Scientific, V.A. Graiciuno, Vilnius, Lithuania). All the cDNA templates were stored at $-20{ }^{\circ} \mathrm{C}$ until further use.

\subsection{Reverse Transcription Quantitative PCR (RT-qPCR) Assay}

The copy number of the virus was determined as per Tattiyapong et al. [15], using Real-Time PCR system (StepOnePlus ${ }^{\mathrm{TM}}$, Applied Biosystems, Mapletree, Singapore) and SYBR green-based qPCR assay. Briefly, the reaction consisted of $12.5 \mu \mathrm{L}$ of $2 \mathrm{X}$ SYBR green master mix (Takara Bio Inc., Kusatsu, Shiga, Japan), $0.5 \mu \mathrm{L}$ ( 20 picomoles per $\mu \mathrm{L}$ ) each of the forward and reverse primers, $2 \mu \mathrm{L}$ of cDNA template and nuclease-free water to make final volume of $25 \mu \mathrm{L}$. The reaction was carried out in duplicate. The qPCR cycling conditions included: 2 min denaturation at $95^{\circ} \mathrm{C}$ followed by 40 cycles of denaturation for $10 \mathrm{~s}$ at $95^{\circ} \mathrm{C}$, annealing and extension for $30 \mathrm{~s}$ at $60^{\circ} \mathrm{C}$. After completion of RT-qPCR, the possibility of non-specific amplification was checked by including a control reaction without cDNA template with each assay and through melt curve analysis. For quantifying the TiLV copy numbers in the samples, the dilution series of plasmid having PCR efficiency $99-100 \%$ was used as the standard. The viral load in liver and brain were determined using three replicates at each time point. The generated data were analyzed using one-way analysis of variance (ANOVA). The results are presented as mean virus copy number per $100 \mathrm{ng}$ of RNA and level of statistical significance $(p)$ was fixed at $<0.05$.

\subsection{Isolation of TiLV}

The filtered tissue homogenate was prepared from pooled liver and brain tissues of the experimentally infected carps and tilapia at $6 \mathrm{dpi}$ following Behera et al. [11]. Briefly, pooled tissues from 3 fish of each species were homogenized using Leibovitz's (L-15) medium (Life Technologies, Darmstadt, Germany). The homogenate was centrifuged and the supernatant was filtered using a $0.45 \mu \mathrm{m}$ filter. The filtered supernatant from each fish species was inoculated in monolayer of permissive CFF cell line $\left(25 \mathrm{~cm}^{2}\right.$ flasks $)$ derived from fin of Pristolepis fasciatus [16] and were kept at $28{ }^{\circ} \mathrm{C}$. L-15 medium containing $2 \%$ FBS (maintenance medium) was used in control flasks. Following adsorption at $28^{\circ} \mathrm{C}$ for $1 \mathrm{~h}$, the filtrate was aspirated and $5 \mathrm{~mL}$ of maintenance medium was added to each flask. Flasks were observed under an inverted microscope for development of cytopathic effects (CPE) up to 12 days post-inoculation (dpi). Subsequently, the cell pellet from each flask was collected in TRI Reagent and kept in ultrafreezer $\left(-80^{\circ} \mathrm{C}\right)$ for subsequent detection of TiLV using RT-PCR [17].

\section{Results and Discussion}

Viruses, in general, are reported to be host-specific but viruses affecting lower vertebrates including fishes are reported to have broad host-range [18]. For example, lymphocystis disease virus (LCDV) and aquatic birnaviruses are reported to have more than 140 and 80 susceptible hosts, respectively [19,20]; whereas viral nervous necrosis virus has been reported from over 177 susceptible marine species [21]. Although TiLV has been reported to primarily infect tilapines [3], the giant gourami (O. goramy) has been reported to be susceptible to natural and experimental infection with the virus $[5,22]$. Furthermore, TiLV has been detected in wild B. schwanenfeldii [6] and L. calcarifer [7]. However, to date, there is no report of TiLV-associated mortality in non-tilapines except in O. goramy [4]. But there is a possibility that other fish species could be susceptible or serve as a carrier for the transmission of this virus [14]. Therefore, in the present study, we evaluated the susceptibility of three carps (C. catla, C. mrigala and H. molitrix) to TiLV following experimental infection. It was observed that the three species of carps were refractory to TiLV infection during the 12-day experimental period. Nevertheless, the experimentally-challenged tilapia showed susceptibility to the virus. The present observation of non-susceptibility of 
carps to TiLV assumes significance in the context of co-cultivation of carps and tilapia in South Asian countries.

\subsection{Clinical Signs and Mortality Pattern in Experimentally Infected Fishes}

In the present study, in experimentally-infected tilapia, the clinical signs included lethargy, exophthalmia, abdominal swelling followed by death. The mortality started $6 \mathrm{dpi}$ and all the tilapia died by $12 \mathrm{dpi}$. Similar clinical signs have been reported in tilapia in natural and experimental infection with TiLV $[8,11,17,23]$. In contrast, clinical signs and mortality were not observed in TiLV-injected carps during the experiment (Figure 1). These findings are in conformity with earlier reports in L. rohita, C. carpio, B. gonionotus, P. hypophthalmus, C. striata, C. macrocephalus, A. testudineus, T. pectoralis, L. calcarifer, E. suratensis, P. maculatus, and E. canarensis following experimental infection with TiLV [8,22]. Furthermore, in accordance with our findings, no clinical signs and mortality have been reported in many fish species cultured along with tilapia, namely C. carpio, C. catla, L. rohita, C. mrigala, Mugil cephalus, Liza ramada, Chanos chanos and E. suratensis in natural outbreaks [2,10,11].
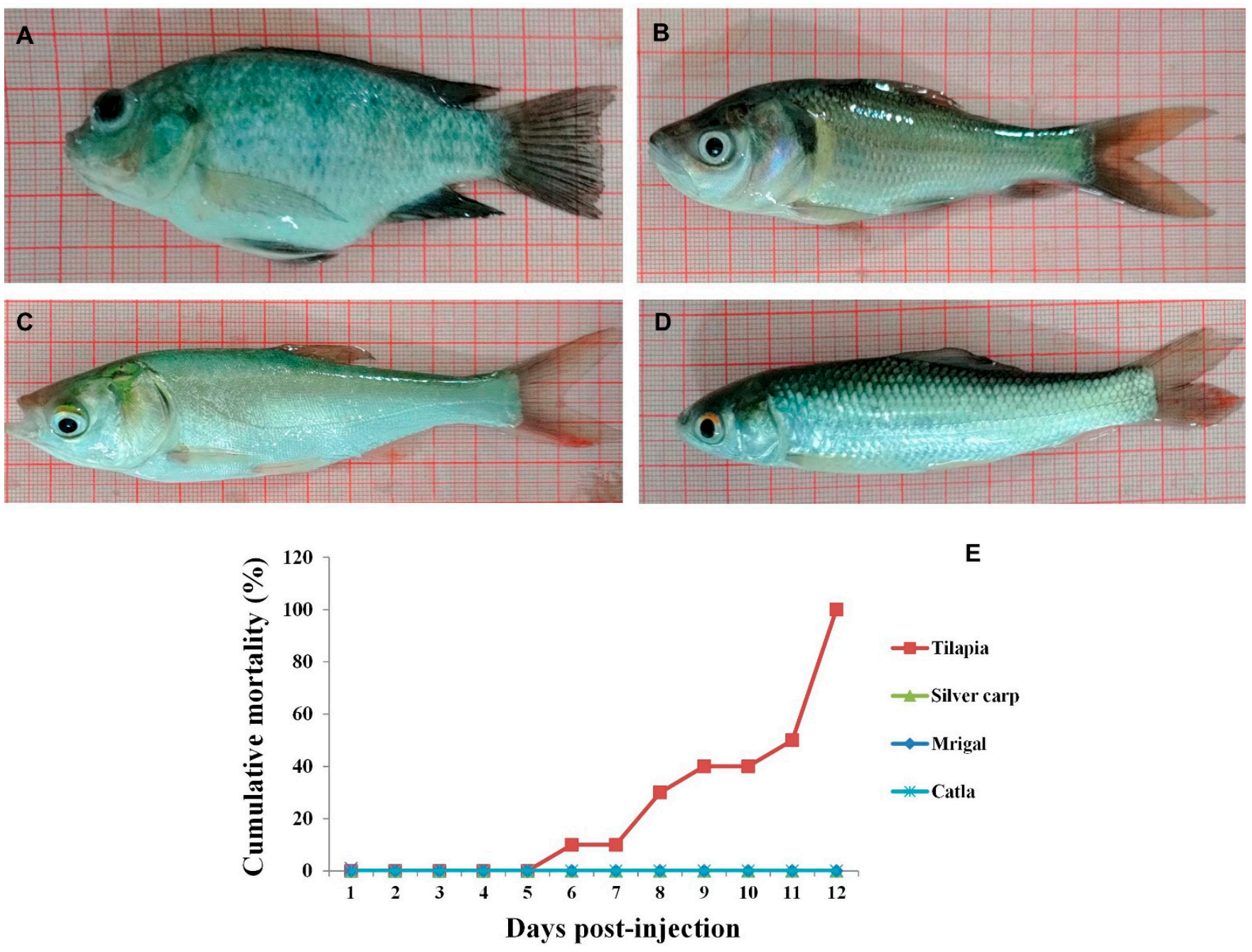

Figure 1. Gross appearance of tilapia (A), catla (B), silver carp (C) and mrigal (D) at 6 days following injection with Tilapia lake virus. Abdominal swelling and exophthalmia were observed only in tilapia whereas carps did not show any gross lesions. (E). Mortality curve of carps and tilapia following experimental injection with TiLV. All the TiLV-injected tilapia died by 12 days post-injection. No mortality was observed in any of the carps. 


\subsection{Histopathological Examination}

Typical syncytial cells were observed in liver of experimentally infected tilapia at $6 \mathrm{dpi}$ (Figure 2A). In addition, necrosis of hepatocytes and eosinophilic material in the cytoplasm of hepatocytes were observed. The histopathological alterations in liver of TiLV-infected fish were consistent with earlier reports [23]. In contrast, histopathological changes typical of TiLV infection could not be observed in liver of carps following experimental infection (Figure 2B-D). This is in accordance with the previous histopathological findings reported in different cyprinids namely C. carpio, B. gonionotus and L. rohita $[8,22]$.
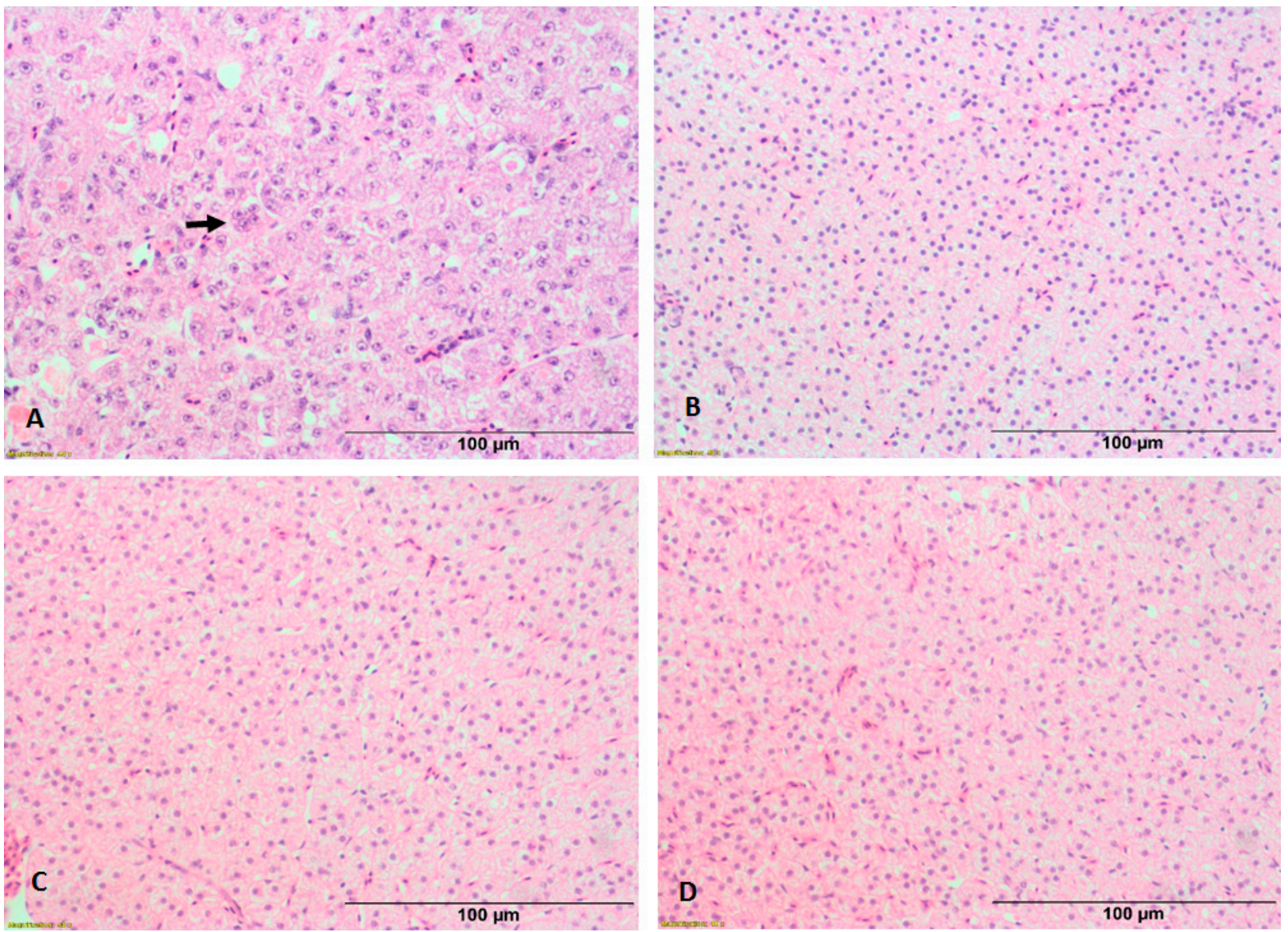

Figure 2. Histopathological lesions in liver of experimentally infected fishes. Typical syncytial cells (arrows) were observed in tilapia (A). No lesions were observed in liver of Catla catla (B), Cirrhinus mrigala (C) and Hypophthalmichthys molitrix (D).

\subsection{Estimation of Viral Copy Number in Experimentally-Injected Fish}

Quantitative estimation of TiLV copy numbers in two target organs, liver and brain of the experimentally-infected carps and tilapia was carried out at 1, 6 and 12 days postinjection, using RT-qPCR. The results obtained from three biological replicates are presented as mean TiLV copy numbers in $100 \mathrm{ng}$ of total RNA (Figure 3). In all the three carps, i.e., C. catla, C. mrigala, and H. molitrix, TiLV copies were negligible i.e., $<5$ in both the tissues in all the time-points. Further, TiLV copy number didn't increase over the time points. Contrastingly, in the experimentally-infected tilapia, higher viral copy numbers i.e., $7.7 \times 10^{3}$ and $5.8 \times 10^{2}$ copies were detected at $1 \mathrm{dpi}$ in liver and brain, respectively. This was followed by a significant increase $(p<0.05)$ in the viral load in both liver and brain $\left(6.9 \times 10^{7}\right.$ and $3.6 \times 10^{7}$ copies, respectively) at 6 dpi. At $12 \mathrm{dpi}$, the viral copy number showed marginal decline in liver $\left(4.0 \times 10^{7}\right.$ copies $)$ and remained almost similar $\left(3.7 \times 10^{7}\right.$ copies $)$ to that observed at $6 \mathrm{dpi}$. Previously, studies on the quantitative estimation of TiLV load in experimentally-challenged host species are limited $[8,22,24,25]$. It is interesting to note 
that while eight warm water fish species challenged with TiLV showed no detectable viral copies using qRT-PCR, the giant gourami showed $1.96 \times 10^{2}$ copies/ $\mu$ g of RNA, in 5 out of 15 fishes at 5 days post-challenge [5]. However, unlike in the present study, the giant gourami showed clinical and histopathological manifestations of TiLV infection apart from the fishes showing positive in situ hybridization signals and successful virus isolation. Though detectable viral load could be noticed in carps at initial stage of the experiment, the viral copy number declined at subsequent time points. It is important to note that previous reports on other fish viruses such as IPNV and CyHV-3 also showed discernible viral load in resistant fishes [26,27]. Further, in the current study, lack of gross and histopathological alterations in experimentally challenged carps could be due to negligible viral copy number in these species. Though the exact mechanism is not known, it can be inferred from the present study that TiLV failed to replicate in these three carps during the experimental period ( $12 \mathrm{dpi}$ ). Therefore, the present report adds additional species to list of previously reported cyprinids C. carpio and L. rohita, that have been reported to be resistant/non-susceptible to TiLV [8,22].
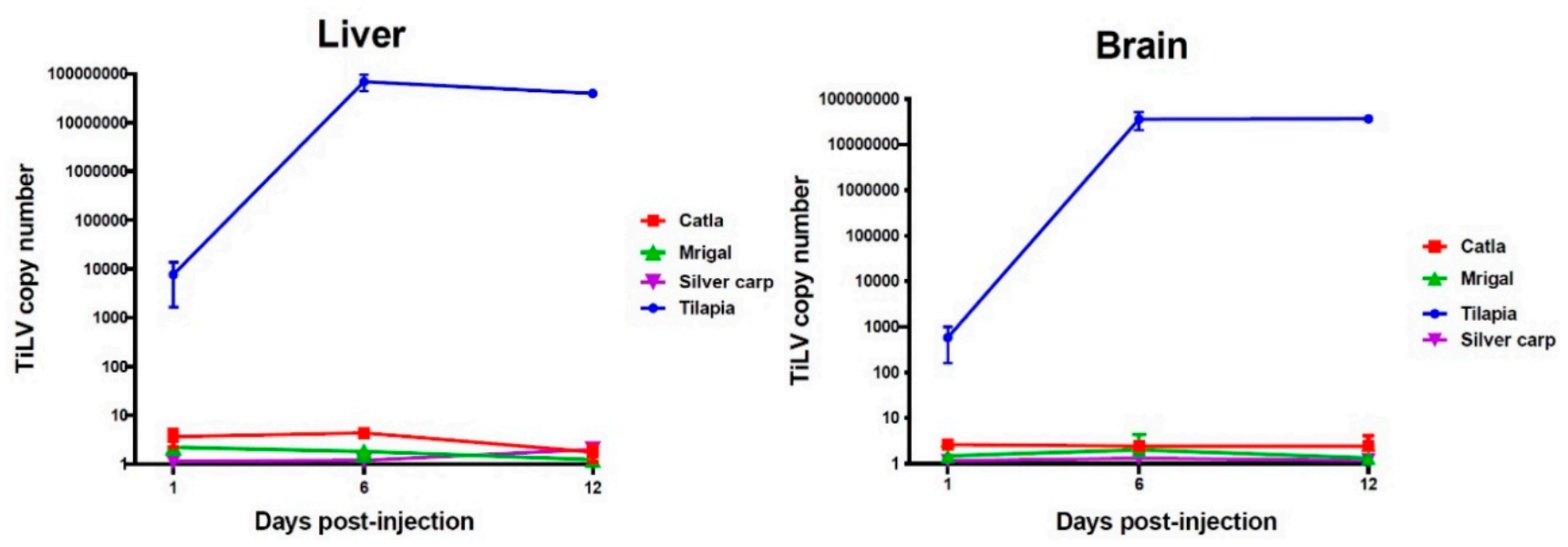

Figure 3. TiLV copy numbers in carps and tilapia following experimental infection with TiLV at different time points, as quantified by RT-qPCR.

\subsection{Re-Isolation of TiLV}

For confirming the presence of infectious TiLV, filtered tissue homogenate obtained from pooled liver and brain of each fish species at 6 dpi was inoculated separately in permissive CFF cell line. This time point was selected as the TiLV copy number has been reported to be maximum in liver and brain of susceptible species [8].Cytopathic effects were noticed in CFF cell line following inoculation with homogenate from TiLVinfected tilapia only and these included elongation, rounding and detachment of cells from the surface (Figure 4A). By 12 days after inoculation, more than $80 \%$ of the cells had detached. Furthermore, TiLV was detected in cell pellet from the inoculated flask using RT-PCR. In contrast, CPE was not observed in any of the flasks inoculated with filtered homogenate from any of the three carps up to 12 days post-inoculation (Figure 4B-D), and the cell pellets from the inoculated flasks were negative for TiLV by nested RT-PCR. These findings further suggested that TiLV was able to replicate in CFF cells inoculated only with filtered tissue homogenate prepared from pooled liver and brain tissues of TiLV-infected tilapia. Importantly, though a few virus copies were detected in tissues of carps using RT-qPCR, but these appeared to be non-infectious as indicated by lack of demonstrable CPE and negative RT-PCR results. These findings are consistent with earlier studies where koi herpesvirus could not be isolated from crucian carp (Carassius auratus langsdorfii) following experimental infection [28]. Similar to the findings of the present study, infectious salmon anemia virus could not replicate or persist in saithe (Pollachius virens), following experimental infection [29]. 

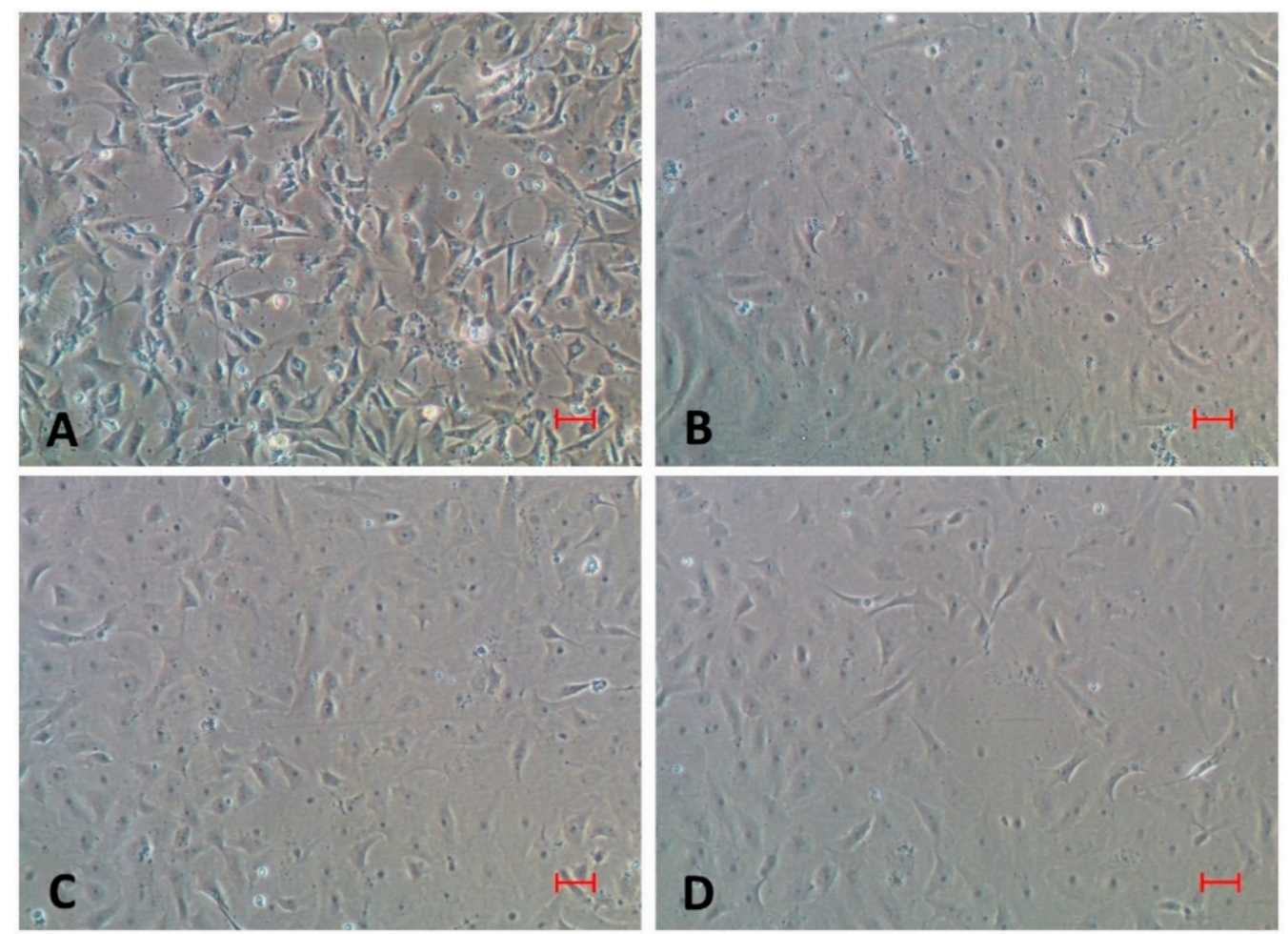

Figure 4. Cytopathic effects (CPE) in CFF cell line following inoculation with homogenate from tilapia at 12 days post-inoculation (A). Please note that no CPE was observed in cell line after inoculation of homogenate from C. catla (B), C. mrigala (C) and H. molitrix (D). Bar represents $50 \mu \mathrm{m}$.

\section{Conclusions}

In conclusion, none of the three carp species, namely C. catla, C. mrigala and H. molitrix was found to be susceptible to experimental infection of TiLV, as evidenced by lack of clinical signs, mortality, histopathological alterations, cytopathic effects as well as no increase in TiLV copy numbers with the time course. It is unlikely that these three carps would act as carriers of TiLV. Therefore, findings of the present study are important as these carps are commonly co-cultured with tilapia in the South Asian countries.

Author Contributions: Conceptualization, P.K.P. and N.S.; methodology, D.K.V., S.C.Y. and A.K.D.; analysis, D.K.V. and A.P.; writing — original draft preparation, N.S., P.K.P. and D.K.V. writing-review and editing, R.K.V., T.R.S.; project administration, P.K.P., N.S. and R.K.V.; funding acquisition, P.K.P. and R.K.V. All authors have read and agreed to the published version of the manuscript.

Funding: The funding support from National Agricultural Science Fund, Indian Council of Agricultural Research (Grant Number: NASF/ABA-8006/2019-20/162) is gratefully acknowledged.

Institutional Review Board Statement: The experiments involving live fish were evaluated and duly approved by the Institutional Animal Ethics Committee (IAEC) of ICAR-National Bureau of Fish Genetic Resources, Lucknow (NBFGR/IAEC/2020/029).

Acknowledgments: The authors express their gratitude to Kuldeep K. Lal, Director, ICAR-NBFGR and Gopal Krishna, Director, ICAR-CIFE for providing the necessary facilities. The authors are also thankful to J.K. Jena, DDG (Fy. Sc.) for his support and guidance.

Conflicts of Interest: The authors declare that there is no conflict of interest. 


\section{References}

1. Adams, M.J.; Lefkowitz, E.L.; King, A.M.Q.; Harrach, B.; Harrison, R.L.; Kropinski, N.J.; Krupovic, M.; Kuhn, J.H.; Mushegian, A.R.; Nibert, M.; et al. Changes to taxonomy and the international code of virus classification and nomenclature ratified by the international committee on taxonomy of viruses. Arch. Virol. 2017, 162, 2505-2538. [CrossRef] [PubMed]

2. Eyngor, M.; Zamostiano, R.; Tsofack, J.E.K.; Berkowitz, A.; Bercovier, H.; Tinman, S.; Lev, M.; Hurvitz, A.; Galeotti, M.; Bacharach, E.; et al. Identification of a novel RNA virus lethal to tilapia. J. Clin. Microbiol. 2014, 52, 4137-4146. [CrossRef]

3. Jansen, M.D.; Dong, H.T.; Mohan, C.V. Tilapia lake virus: A threat to the global tilapia industry? Rev. Aquac. 2019, 11, 725-739. [CrossRef]

4. Surachetpong, W.; Roy, S.R.K.; Nicholson, P. Tilapia lake virus: The story so far. J. Fish Dis. 2020, 43, 1115-1132. [CrossRef]

5. Jaemwimol, P.; Rawiwan, P.; Tattiyapong, P.; Saengnual, P.; Kamlangdee, A.; Surachetpong, W. Susceptibility of important warm water fish species to tilapia lake virus (TiLV) infection. Aquaculture 2018, 497, 462-468. [CrossRef]

6. Abdullah, A.; Ramly, R.; Mohammad Ridzwan, M.S.; Sudirwan, F.; Abas, A.; Ahmad, K.; Murni, M.; Kua, B.C. First detection of tilapia lake virus (TiLV) in wild river carp (Barbonymus schwanenfeldii) at Timah Tasoh Lake, Malaysia. J. Fish Pathol. 2018, 41, 1459-1462. [CrossRef] [PubMed]

7. Piamsomboon, P.; Wongtavatchai, J. Detection of Tilapia Lake Virus (TiLV) in healthy fish from the pre-existing disease environment using different RT-PCR methods. Turkish J. Fish. Aquat. Sci. 2021, 21, 205-209. [CrossRef]

8. Pradhan, P.K.; Paria, A.; Yadav, M.K.; Verma, D.K.; Gupta, S.; Swaminathan, T.R.; Rathore, G.; Sood, N.; Lal, K.K. Susceptibility of Indian major carp Labeo rohita to tilapia lake virus. Aquaculture 2020, 515, 734567. [CrossRef]

9. Thangaraj, R.S.; Nithianantham, S.R.; Narendrakumar, L.; Johny, T.K.; Sood, N.; Pradhan, P.K.; Lal, K.K. Cichlids endemic to India are not susceptible to tilapia lake virus infection. Aquaculture 2021, 548, 737589. [CrossRef]

10. Fathi, M.; Dickson, C.; Dickson, M.; Leschen, W.; Baily, J.; Muir, F.; Ulrich, K.; Weidmann, M. Identification of Tilapia Lake Virus in Egypt in Nile tilapia affected by 'summer mortality' syndrome. Aquaculture 2017, 473, 430-432. [CrossRef]

11. Behera, B.K.; Pradhan, P.K.; Swaminathan, T.R.; Sood, N.; Paria, P.; Das, A.; Verma, D.K.; Kumar, R.; Yadav, M.K.; Dev, A.K.; et al. Emergence of Tilapia lake virus associated with mortalities of framed Nile tilapia Oreochromis niloticus (Linneaus 1758) in India. Aquaculture 2018, 484, 168-174. [CrossRef]

12. Menaga, M.; Fitzsimmons, K. Growth of the Tilapia industry in India. World Aquac. 2017, 48, 49-52.

13. Chaput, D.L.; Bass, D.; Alam, M.M.; Al Hasan, N.; Stentiford, G.D.; Van Aerle, R.; Moore, K.; Bignell, J.P.; Haque, M.M.; Tyler, C.R. The segment matters: Probable reassortment of tilapia lake virus (TiLV) complicates phylogenetic analysis and inference of geographical origin of new isolate from Bangladesh. Viruses 2020, 12, 258. [CrossRef]

14. Food and Agriculture Organization of the United Nations (FAO). Outbreaks of Tilapia Lake Virus (TiLV) Threaten the Livelihoods and Food Security of Millions of People Dependent on Tilapia Farming. In Global Information and Early Warning System (GIEWS) Special Alert No. 338; FAO: Rome, Italy, 2017; Available online: http:/ /www.fao.org/documents/card/en/c/3ce1da5b-1529-4e7c8b88-7adfef8d138c/ (accessed on 12 August 2021).

15. Tattiyapong, P.; Sirikanchana, K.; Surachetpong, W. Development and validation of a reverse transcription quantitative polymerase chain reaction for tilapia lake virus detection in clinical samples and experimentally challenged fish. J. Fish Dis. 2018, 41, 255-261. [CrossRef]

16. Swaminathan, T.R.; Basheer, V.S.; Gopalakrishnan, A.; Rathore, G.; Chaudhary, D.K.; Kumar, R.; Jena, J.K. Establishment of caudal fin cell lines from tropical ornamental fishes Puntius fasciatus and Pristolepis fasciata endemic to the Western Ghats of India. Acta Trop. 2013, 128, 536-541. [CrossRef]

17. Dong, H.T.; Siriroob, S.; Meemetta, W.; Santimanawong, W.; Gangnonngiw, W.; Pirarat, N.; Khunrae, P.; Rattanarojpong, T.; Vanichviriyakit, R.; Senapin, S. Emergence of tilapia lake virus in Thailand and an alternative semi-nested RT PCR for detection. Aquaculture 2017, 476, 111-118. [CrossRef]

18. Bandín, I.; Dopazo, C.P. Host range, host specificity and hypothesized host shift events among viruses of lower vertebrates. Vet. Res. 2011, 42, 67. [CrossRef]

19. Pontejo, S.M.; Sánchez, C.; Martín, R.; Mulero, V.; Alcami, A.; Alejo, A. An orphan viral TNF receptor superfamily member identified in lymphocystis disease virus. Virol. J. 2013, 10, 188. [CrossRef] [PubMed]

20. Reno, P.W. Infectious pancreatic necrosis and associated aquatic birnaviruses. In Fish Diseases and Disorders; Woo, P.T.K., Bruno, D.W., Eds.; CAB International Wallingford UK: New York, NY, USA, 1999; pp. 1-55.

21. Bandín, I.; Souto, S. Betanodavirus and VER Disease: A 30-year Research Review. Pathogens 2020, 9, 106. [CrossRef]

22. Chiamkunakorn, C.; Machimbirike, V.I.; Senapin, S.; Khunrae, P.; Dong, H.T.; Rattanarojpong, T. Blood and liver biopsy for the non-destructive screening of tilapia lake virus. J. Fish Dis. 2019, 42, 1629-1636. [CrossRef]

23. Ferguson, H.; Kabuusu, R.; Beltran, S.; Reyes, E.; Lince, J.; Del Pozo, J. Syncytial hepatitis of farmed tilapia, Oreochromis niloticus (L.): A case report. J. Fish Dis. 2014, 37, 583-589. [CrossRef]

24. Waiyamitra, P.; Piewbang, C.; Techangamsuwan, S.; Liew, W.C.; Surachetpong, W. Infection of Tilapia tilapinevirus in Mozambique Tilapia (Oreochromis mossambicus), a globally vulnerable fish species. Viruses 2021, 13, 1104. [CrossRef]

25. Mugimba, K.K.; Tal, S.; Dubey, S.; Mutoloki, S.; Dishon, A.; Evensen, Ø.; Munang'andu, H.M. Gray (Oreochromis niloticus x O. aureus) and Red (Oreochromis spp.) Tilapia Show Equal Susceptibility and Proinflammatory Cytokine Responses to Experimental Tilapia Lake Virus Infection. Viruses 2019, 11, 893. [CrossRef] 
26. Robledo, D.; Taggart, J.B.; Ireland, J.H.; McAndrew, B.J.; Starkey, W.G.; Haley, C.S.; Hamilton, A.; Guy, D.R.; Mota-Velasco, J.C.; Gheyas, A.A.; et al. Gene expression comparison of resistant and susceptible Atlantic salmon fry challenged with Infectious pancreatic necrosis virus reveals a marked contrast in immune response. BMC Genom. 2016, 17, 279. [CrossRef]

27. Tadmor-Levi, R.; David, L. Studying the genetics of resistance to CyHV-3 disease using introgression from feral to cultured common carp strains. Front. Genet. 2017, 8, 24. [CrossRef]

28. Kim, H.J.; Kwon, S.R.; Olesen, N.J.; Yuasa, K. The susceptibility of silver crucian carp (Carassius auratus langsdorfii) to infection with koi herpesvirus (KHV). J. Fish Dis. 2019, 42, 1333-1340. [CrossRef] [PubMed]

29. Snow, M.; Raynard, R.; Bruno, D.W.; van Nieuwstadt, A.P.; Olesen, N.J.; Løvold, T.; Wallace, C. Investigation into the susceptibility of saithe Pollachius virens to infectious salmon anaemia virus (ISAV) and their potential role as a vector for viral transmission. Dis. Aquat. Org. 2002, 50, 13-18. [CrossRef] [PubMed] 